\title{
Scheuermann disease presenting as compressive myelopathy
}

Figure $\quad$ MRI thoracic spine

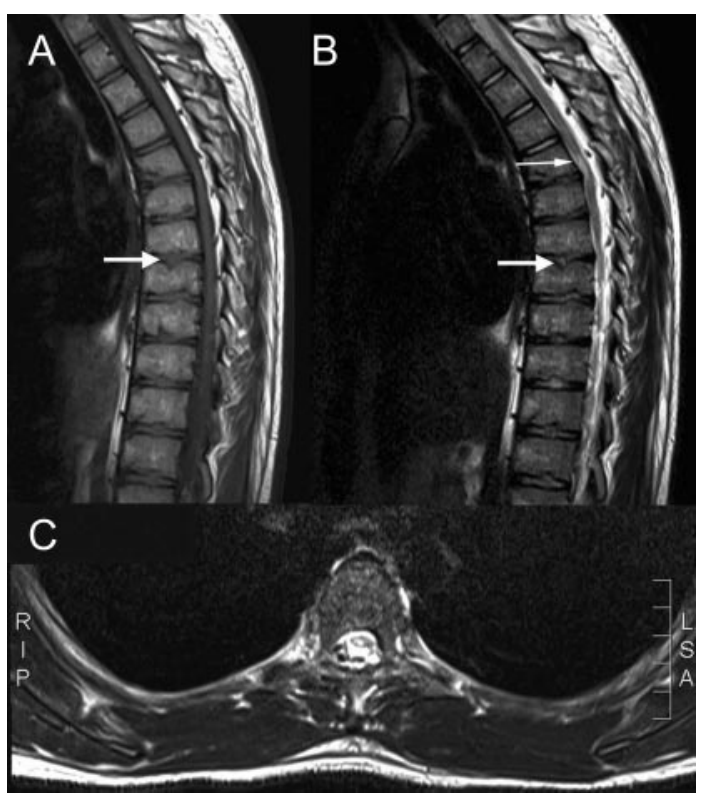

(A) Sagittal T1-weighted and (B) sagittal T2-weighted image showing dorsal kyphosis and Schmorl nodes (arrows) at multiple dorsolumbar levels with spinal cord thinning and T2 hyperintensity at T6 level (thin arrow). (C) Axial T2-weighted image of spine showing myelomalacia and cord atrophy.

A 17-year-old boy had progressive stiffness of lower limbs and decreased pain and touch sensation on the right, then left, leg for 1 month. He had mild kyphosis, grade IV spasticity, pyramidal pattern of weakness in lower limbs, brisk reflexes, and extensor plantar responses with impaired spinothalamic and posterior column sensation below T7. Imaging suggested Scheuermann disease (figure), which manifests in adolescence as rigid kyphosis with wedging of at least $5^{\circ}$ of each of 3 adjacent vertebrae (Sorensen criteria). ${ }^{1}$ Thoracolumbar Scheuermann disease is type I, which is progressive; if symptomatic, surgical treatment is indicated. Type II or lumbar type is not progressive. ${ }^{2}$

\section{S.A. Jagtap, MD, D. Manuel, MD, C. Kesavdas, MD, M.D. Nair, MD, DM, Kerala, India}

Author contributions: Dr. Jagtap: concept, drafting, and revision of article. Dr. Manuel: drafting. Dr. Kesavdas: drafting, image, and manuscript revision. Dr. Nair: drafting, image, and manuscript revision.

Disclosure: Dr. Jagtap and Dr. Manuel report no disclosures. Dr. Kesavadas serves as an Associate Editor for Neurology India and Section Editor for Journal of Radiology \& Imaging and receives research support from GE Healthcare. Dr. Nair supports no disclosures.

Correspondence \& reprint requests to Dr. Jagtap: sujitjagtap@gmail.com

1. Kapetanos GA, Hantzidis PT, Anagnostidis KS, et al. Thoracic cord compression caused by disk herniation in Scheuermann's disease: a case report and review of the literature. Eur Spine J 2006;15(suppl 5):553-558.

2. Greene TL, Hensinger RN, Hunter LY. Back pain and vertebral changes simulating Scheuermann's disease. J Pediatr Orthop $1985 ; 5: 1-7$. 


\title{
Neurology
}

\author{
Scheuermann disease presenting as compressive myelopathy \\ S.A. Jagtap, D. Manuel, C. Kesavdas, et al. \\ Neurology 2012;78;1279 \\ DOI 10.1212/WNL.0b013e318250d87b
}

This information is current as of April 16, 2012

\section{Updated Information \& Services}

References

Subspecialty Collections

Permissions \& Licensing

Reprints including high resolution figures, can be found at: http://n.neurology.org/content/78/16/1279.full

This article cites 2 articles, 0 of which you can access for free at: http://n.neurology.org/content/78/16/1279.full\#ref-list-1

This article, along with others on similar topics, appears in the following collection(s):

\section{All Spinal Cord}

http://n.neurology.org/cgi/collection/all_spinal_cord MRI

http://n.neurology.org/cgi/collection/mri

Information about reproducing this article in parts (figures,tables) or in its entirety can be found online at:

http://www.neurology.org/about/about_the_journal\#permissions

Information about ordering reprints can be found online:

http://n.neurology.org/subscribers/advertise

Neurology ${ }^{\circledR}$ is the official journal of the American Academy of Neurology. Published continuously since 1951, it is now a weekly with 48 issues per year. Copyright Copyright (? 2012 by AAN Enterprises, Inc.. All rights reserved. Print ISSN: 0028-3878. Online ISSN: 1526-632X.

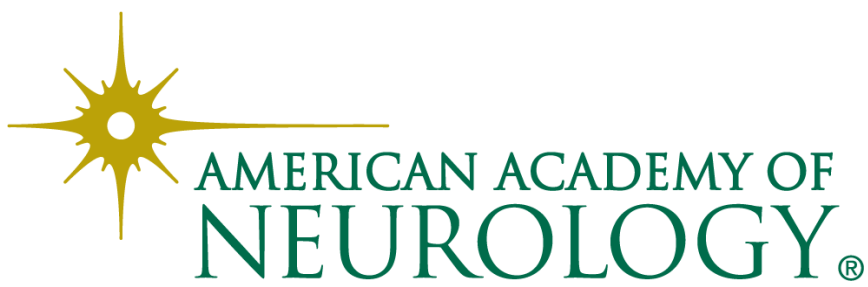

